\title{
Roles of Female Architects in the Process of Design Practice and Their Impacts on Feminist Spaces - Comparison between Genders
}

\author{
Tiantian $\mathrm{Xie}^{1, *}$ \\ ${ }^{1}$ University of Sheffield, School of Architecture, Sheffield, United Kingdom, S10 2TN \\ *Corresponding author. Email: tiantian_xie@163.com
}

\begin{abstract}
Female architects in the professional industry or feminist spaces design are explored as two main aspects or topic in the study of feminism in architecture. Architectural design practice, as collective, cooperative and immaterial work, mostly produces space. In this research, relationship between participation of women architects in the cooperative link of professional team and creation of feminist space is explored. A questionnaire, designed for both male and female architects in China, was sent to architectural design industry forum and chat rooms via internet, discussing female architects' labour division in the team and the implementation of feminist space. In the results, men architects have a certain bias against women architects' strengths and characteristics as well as cognition of feminist compared to that of female's responses. At present, the division of labor in the team is generally dominated by men in the gender-neutral approach of architecture design. Meanwhile, male architects are less aware of feminist spatial needs than women. Increasing female architects' participation in core professional links would have positive effects on design and implementation of feminist space.
\end{abstract}

Keywords: Architecture practice, female architects, feminist spaces

\section{INTRODUCTION}

\subsection{Research background}

Feminism has been drawing public attention in decades all over the world. The Second Sex by Simone de Beauvoir in 1949 explained the basic theory of feminism. Due to the limitation of women's biological basis, in the ancient social production process, women showed less productivity than men, which led to women's subordinate status compared to men. After the industrial revolution, the socialized women of production are gradually taking up their positions in production, and thus have a possibility of equality between men and women on an economic basis [1]. Nevertheless, according to the data collected in 2020, male architects are three times the number of female architects, among the first class registered architects in China [2].

Academies have been exploring the development of feminism in architecture in recent years. Unfortunately, in the culture of architecture, masculine domination atmosphere is the mainstream tendency and the discussion of women architects' work is embedded in the masculine cognition system. And the gender-neutral approach is generally applied in design process. This makes the production of architecture less considerate to gender equality [3].

The working content of architects can be treated as immaterial labour or knowledge work, and feminism in architecture is supposed to be in the context of neoliberal capitalism. This kind of work is, on the one hand, self-driven, internal motivated and self-fulfilling, and on the other hand, precarious and competitive. The process of creative industries includes "communication, teamwork, improvisation, self-management and performing body" [4]. Art work, including architecture work, is more likely to be treated as the cooperation of a number of participants and carried on with collective efforts. The division of labour results from a consensual definition of the situation, and therefore a "convention" exists to mediate the cooperation, and the artists (the chief architects) work in the center of a large network of cooperating people. Conventions regulate the cooperative link of the collective work of creativity. [5] 
Female architects, inevitably, are part of the cooperative link and are also faced with competitive and precarious situation when undertaking this immaterial labour.

Architecture creates space and light communicating with people. By presenting light and space, with other factors taken into consideration, architecture restarts reflection on human consciousness of and connection to how we rebuild and occupy the environment [6]. Space is one of the results of architecture. Feminist space, in this paper, is defined as space applying feminist methodologies and approaches to respond to women's voice in design practice.

However, although female architects' supporters stand for the view that design with more cohesive corporation is more responsive to the needs of women, women clients or users of the architectural design are still uncertain about feminist spatial identities and requirements [7]. Thus the sensitivity on feminist spatial features of architects is of significance in achieving feminism in architecture. In this paper, three aspects of female requirements of space will be discussed: women's needs for spatial functions, female aesthetic tendency and women's security.

\subsection{Research theme}

In this paper, the relationship between female architects' roles to the designing team in architectural practice process and the creation of feminist space will be explored. In order to figure out the research question, elements or factors, such as the division of labour, the working characteristics, understanding of feminist space of female architects, will be discussed and analyzed.

\subsection{Research method}

As a pilot study for the research question, a questionnaire was designed for both male and female architects so as to make a comparison between genders. Architects from all over China will be invited to fill the structured form and most of the questions are multiple choices.
Contribution of female architects and feminist space are mostly discussed in academic literature as two separated and independent issues. Exploring the causal relationship between those two research directions is not only conducive to linking and integrating existing research results thus finding out the mechanism of promoting feminism in architectural design practice, but also instructive to how to make more possibilities for female architects to play a greater role in the cooperative link, how to respond to the specific characteristic of female architects or how to promote feminist space and imply feminist spatial elements in the design process.

\section{METHODOLOGY}

The questions in the questionnaire can be divided into four major parts. First part is background information of participants, such as gender, years of working and position. Second part is female architects in collective design practice, such as professional skills. Third part is discussion on feminist spaces, such as the understanding of feminist space and experience of taking feminism into consideration in the designing process. Last part is about relationship between female architects and feminist spaces. The four parts are in a linear serial logical relation subject to research theme.

\subsection{Background information of participants}

The questionnaire was sent to architects from all over China via internet and 76 responses were collected, in which 19 responses from male architects and 57 responses from female architects (Figure 1). Female architects seemed to be more interested in filling the questionnaire, considering the fact that men have the advantage in numbers in architecture field. The age group of architects participating in the questionnaire was 21 to 40 years old and $72.37 \%$ of them were not over thirty. Less than thirty percent of participants had working experience of more than 5 years (Figure 2), only $25 \%$ of the participants were in the position of main/chief architects (Figure 3). Those participants are mostly less-experienced architects.

\subsection{Research significance}

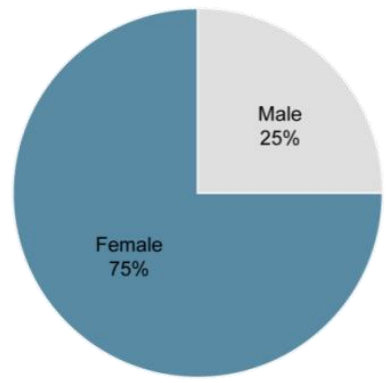

Figure 1 Overall gender ratio

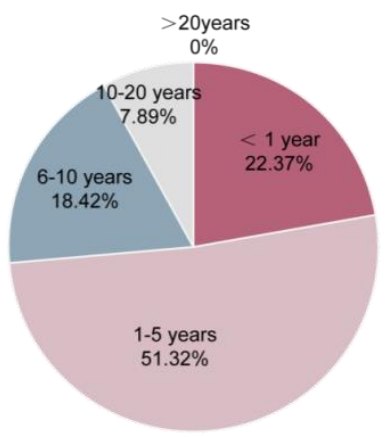

Figure 2 Years of working

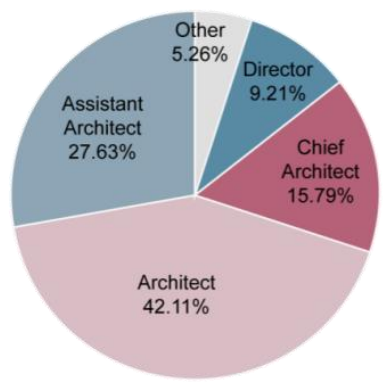

Figure 3 Position as architects 
According to the data collected, the scale of the companies of the samples was proportional (Figure 4). Most of those companies hired less female architects than male ones. (Figure 5) Male/female head architects ratio was approximately 2.3 (Table 1 ). The contrast between the male and female ratio of the number of architects in overall scale and that in principle creative staff shows that a higher proportion of men are in the leading roles in the architectural design and creation compared to female.

Table 1. Male/female head architects ratio

\begin{tabular}{|l|l|}
\hline number & text responds \\
\hline 2 & $8: 2$ \\
\hline 3 & $2: 1$ \\
\hline 4 & $7: 1$ \\
\hline 5 & $8: 2$ \\
\hline 6 & $1.5: 1$ \\
\hline 7 & $1: 3$ \\
\hline 8 & $1: 1$ \\
\hline 9 & $1: 3$ \\
\hline 10 & $3: 7$ \\
\hline 11 & $2: 6$ \\
\hline 12 & $1: 0$ \\
\hline 13 & $8: 2$ \\
\hline 14 & $2: 1$ \\
\hline 15 & $5: 5$ \\
\hline 16 & $1: 2$ \\
\hline
\end{tabular}

\begin{tabular}{|l|l|}
\hline number & text responds \\
\hline 17 & $6: 1$ \\
\hline 18 & $5: 1$ \\
\hline 19 & 6.4 \\
\hline 20 & $5: 2$ \\
\hline 21 & $9: 1$ \\
\hline 22 & $5: 1$ \\
\hline 23 & $1: 1$ \\
\hline 24 & $1: 7$ \\
\hline 25 & $2: 1$ \\
\hline 26 & $1: 1$ \\
\hline 27 & $4: 1$ \\
\hline 28 & $1.1: 1$ \\
\hline 29 & $1: 1$ \\
\hline 30 & $3: 1$ \\
\hline
\end{tabular}

\begin{tabular}{|l|l|}
\hline number & text responds \\
\hline 31 & $3: 2$ \\
\hline 32 & $1: 1$ \\
\hline 33 & $5: 1$ \\
\hline 34 & $1: 7$ \\
\hline 35 & $1: 2$ \\
\hline 36 & $2: 0$ \\
\hline 37 & $1: 1$ \\
\hline 38 & $3: 1$ \\
\hline 39 & $10: 1$ \\
\hline 40 & $10: 1$ \\
\hline 41 & $3: 1$ \\
\hline 42 & $5: 1$ \\
\hline 43 & $4: 1$ \\
\hline 44 & $3: 1$ \\
\hline
\end{tabular}

\begin{tabular}{|l|l|}
\hline number & text responds \\
\hline 45 & $1: 5$ \\
\hline 46 & $1: 4$ \\
\hline 47 & $3: 1$ \\
\hline 48 & $7: 5$ \\
\hline 49 & $2: 3$ \\
\hline 50 & $3: 2$ \\
\hline 51 & no female leader \\
\hline 53 & $3: 7$ \\
\hline 54 & $6: 1$ \\
\hline 55 & $3: 4$ \\
\hline 56 & $10: 1$ \\
\hline 57 & $20: 1$ \\
\hline 58 & $2: 1$ \\
\hline 59 & $1: 1$ \\
\hline 61 & $7: 1$ \\
\hline
\end{tabular}

\begin{tabular}{|l|l|}
\hline number & text responds \\
\hline 62 & $6: 3$ \\
\hline 63 & $10: 1$ \\
\hline 64 & $2: 1$ \\
\hline 65 & $5: 1$ \\
\hline 66 & $7: 3$ \\
\hline 67 & $5: 0$ \\
\hline 68 & $1: 5$ \\
\hline 69 & no female leader \\
\hline 70 & $5: 1$ \\
\hline 71 & no female leader \\
\hline 72 & $9: 1$ \\
\hline 73 & $1: 1$ \\
\hline 74 & $7: 3$ \\
\hline 76 & $1: 0$ \\
\hline
\end{tabular}

More than half of those architects worked for private enterprises, more than one third of them were in state-owned enterprises and less than 1/10 of them were employed by overseas-funded enterprises (Figure 6). In the architecture industry, architects are inevitably exposed to the market environment. Performance is measured in terms of whether an architect can be a productive workforce with enough workload and, more importantly, contributing indispensable work to the team.

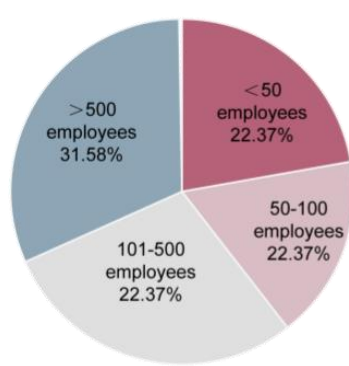

Figure 4 Numbers of employees

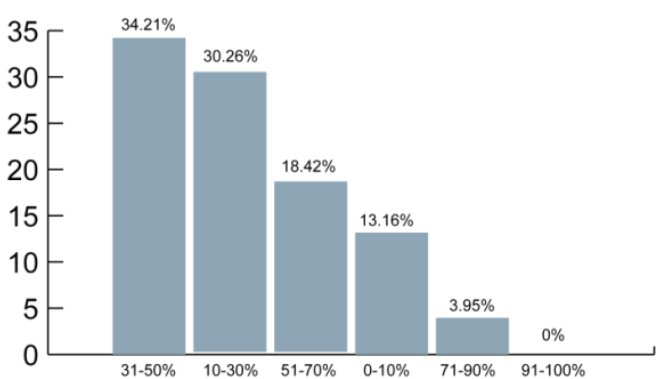

Figure 5 Proportion of female architects

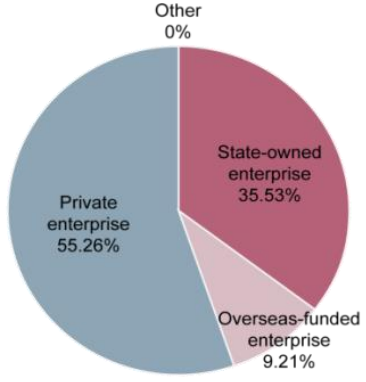

Figure 6 Type of enterprises
Opinions from those samples will be analyzed by comparing responses from different genders on female architects and feminist spaces.

\subsection{Female architects in collective design practice}

In regard to adept professional skills, male architects tend to have balanced development of each required skill, while female architects are better at graphic analysis/documentation as can be seen in Figure 7 . While in design process, graphic analysis is one of the assisting works in project creation and performance.
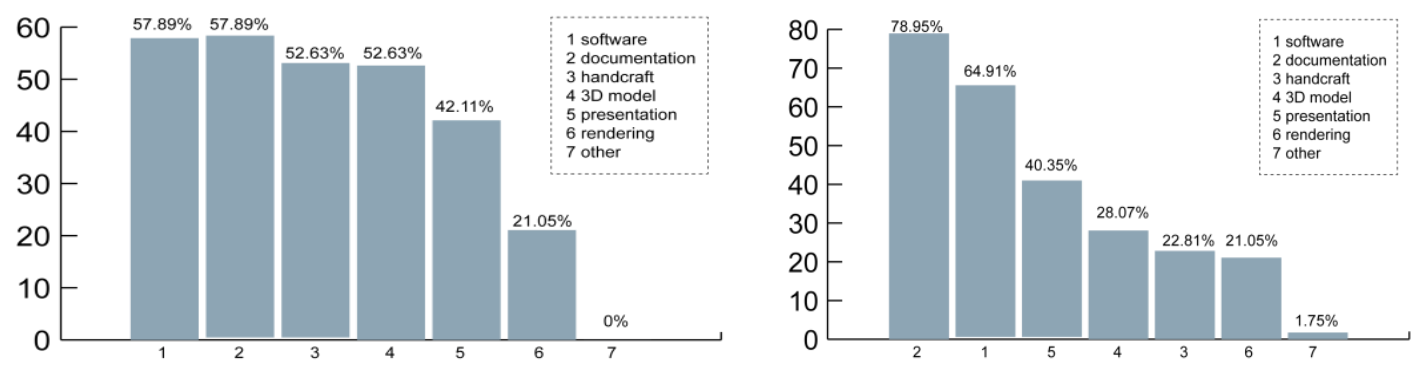

Figure 7 Adept professional skills (male \& female)

Participants' opinions differ on both advantages in cooperative link and thinking characteristic. Both male and female architects think female architects are better at pre-phase analysis and graphic analysis/documentation, which is accordant to adept professional skills of female architects as shown in previous questions (Figure 8). As for thinking characteristic of female architects, male architects think 
females pays more attention on aesthetic pursuit and design details, while more than half of the female participants believe that, except appearance and details as mentioned, they also care about humanistic concern, inspiration of innovation and rigorous logic and these involve the core problems of architectural design scheme creation (Figure 9). The abilities of women architects are recognized in some ways, especially for some supporting work in coordination, but

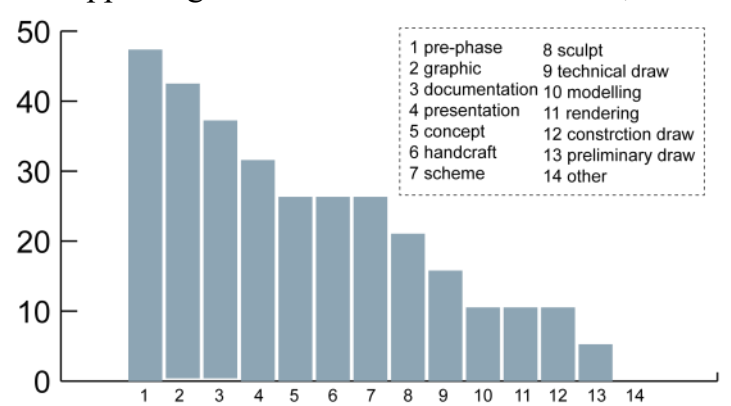

underestimated in other aspects, typically creative and innovative, leading and decision-making work. Every architect has his or her own work ethic, and the architectural team's inherent impression of the capabilities of female architects becomes a psychological hint, having impact on not only women architects' perception of their abilities but also the division of labor for women in the team.

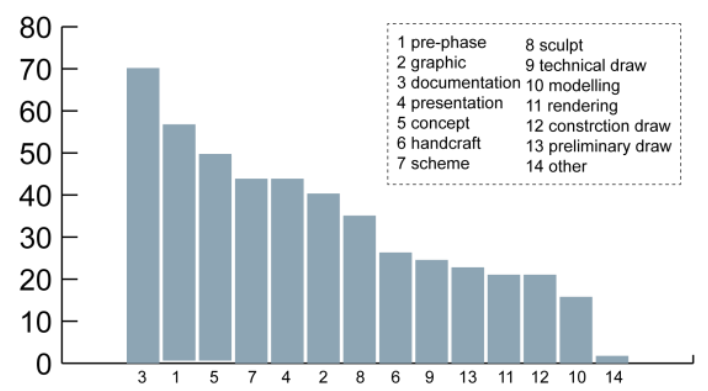

Figure 8 Female architects' advantages (male \& female)
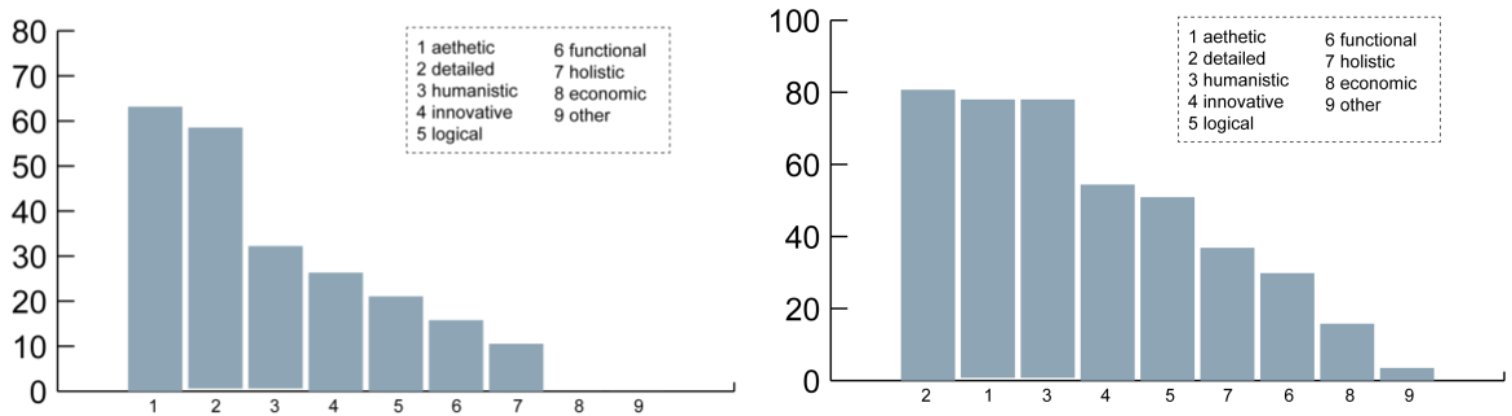

Figure 9 Female architects' thinking characteristics (male \& female)

When it comes to roles and recognition degree of women architects in design groups, opinions from different gender draw to similar results but slightly different trends. Female participants feel they have less role equality than that of male architects' opinions

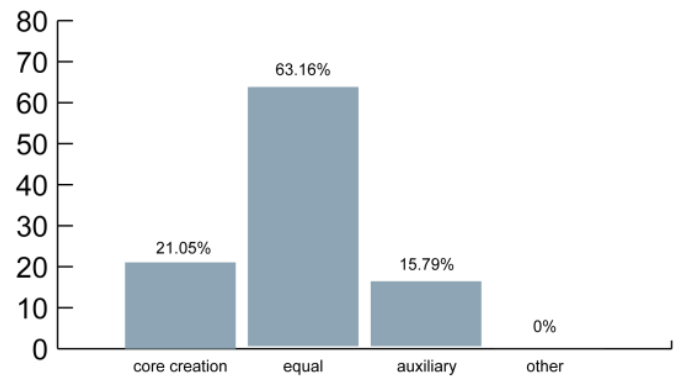

(Figure 10). In general, women architects are more sensitive to the perception of gender inequality than men, and women have less positive attitude and experience towards gender equality.

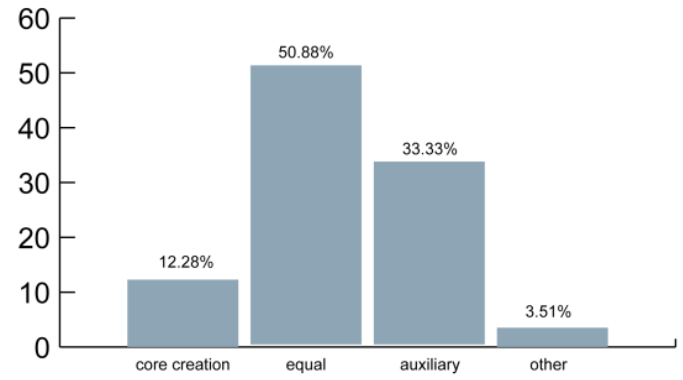

Figure 10 Roles of female architects (male \& female)

\subsection{Discussion on feminist spaces}

Opinions vary from genders about the division of labour, the working characteristics, understanding of feminist space of female architects. When it comes to three empirical elements of feminist space, functional requirement, security issue and aesthetic tendency, spatial function needs are more likely to be implemented in practical projects for both male and female architects, but male designers believe physical safety ranks the second while women designers would choose aesthetic preference (Figure 11). For another, male architects think safety issue is the aspect which matters but hard to be implemented, while female architects think some of the spatial demands of female users are not properly responded (Figure 12). To sum up, male architects hold different views of feminist spaces from female 
architects, and men have misunderstandings about

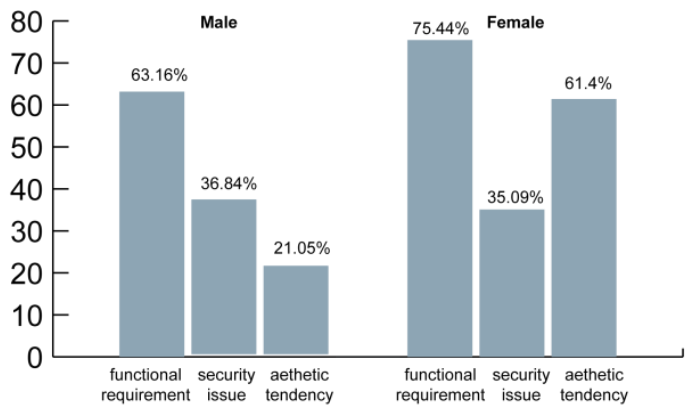

Figure 11 Considered and implemented elements

\subsection{Female architects and feminist spaces}

A larger percentage of female architects believe that the participation of female architects has a positive effect on improving feminist space (Figure 13). Although both male and female architects have awareness of the significant contribution of female architects' impacts on creating feminist spaces, women's need for space.

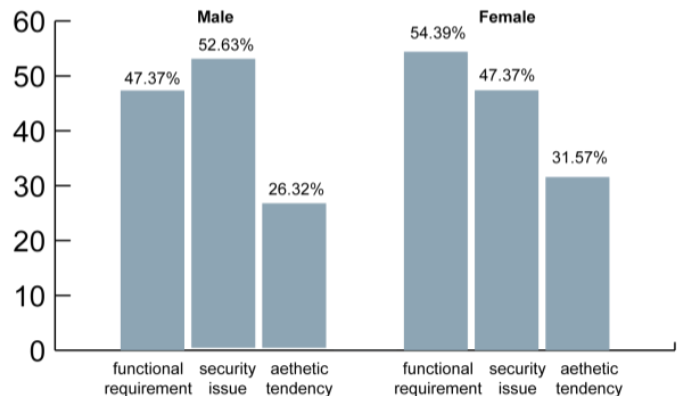

Figure 12 In demand but not implemented elements

cognitive contrast exists between genders. Male architects have understandings of feminist space to some extends. Nevertheless Female architects, also as women users of the outcome of space design, could have better understanding of the requirements of feminist spaces than males.

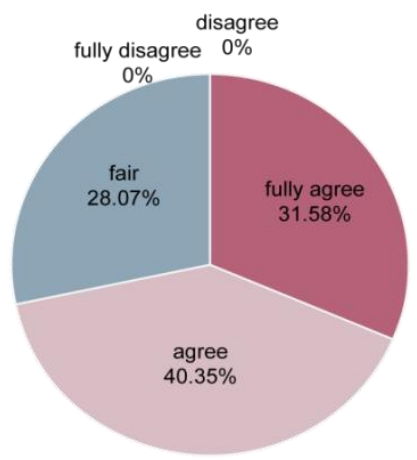

Figure 13 Positive impacts of female architects on feminist spaces (male \& female)

\section{CONCLUSION}

\subsection{Findings and conclusions}

Architecture work is one of the creative immaterial works involving coordination and teamwork. Designers who take over the core creative proposals and the whole project control become the center of the cooperative link of the collective creative work. While women architects are often assigned supportive jobs because of the stereotypes about professional advantages and expectations of women architects. Theses assisting works are usually replaceable, thus making female architects have less power in the creative team. According to the data of Gender ratio of registered architects in China and the first and second part of the questionnaire in this paper, there are far more male architects than female architects and also more head/chief male architects in workplace. Although the achievements of some outstanding women architects cannot be ignored, male architects still dominate the creative process both in numbers and in the division of work.

Spaces, as the products of architectural design projects, are created by the collective effort of practitioner teams of the profession. According to the result of third part of the questionnaire, men have different opinions about feminist space from women and both men and women participants believe that female architects have a better grasp of their needs for feminist space. However, female architects are less likely to speak out and strive for the needs of female users in the gender-neutral designing approach and male-dominated convention.

To sum up, the role and contribution of female architects in the design process plays a positive role in the realization of feminist space. If female architects could have more opportunities to participate in the elaboration of schemes and decision-making in the 
division of labor in the collective work, feminist space would have more chances to be developed.

However, others related to the creative process, such as clients, sponsors, stakeholders, and general users, are not supposed to be ignored, as they can also affect the implementation of feminism in architectural projects. The questionnaire did not take society's general expectations about the role of most women in the family into consideration. The burden of childbirth and family work also diverts time and energy from women, making them less competitive for their career. About feminist space, only three empirical aspects or elements were discussed. Additionally, the number of the samples is of limitation and randomness.

\subsection{Current difficulties and future suggestions}

The current focus on feminism is relatively insensitive in architectural design creation process and market demand. In what convention of collaboration, women architects can really play their roles and exert strengths in the cooperative link and in what architectural design methodology feminist space needs can be realized, become questions worth thinking and studying.

\section{AUTHORS' CONTRIBUTIONS} Xie.

This paper is independently completed by Tiantian

\section{ACKNOWLEDGMENTS}

I would like to express my sincere thanks to Prof. Albena Yaneva of University of Manchester for her patient and enlightening guidance. And thanks very much to my other teachers, my fellows, my families and participants in the research for their support. In addition, wish all female architects, including me, could realize their value in the industry beloved.

\section{REFERENCES}

[1] De Beauvior, S, Second Sex [M] Vintage, 2011.

[2] 80 Architecture, Gender ratio of grade I registered architects, 2020. https://www.sohu.com/a/428249033_200550

[3] Daigneault Deschênes, O, Doing Feminism in Architecture [M] University of British Columbia, 2018.

[4] Frichot, H, \& Gabrielsson, C \& Runting, H, Architecture and Feminism [M] Routledge, 2018.

[5] Becker, H, Art as collective action [J] American Sociological Review, vol.39, no.6, 1974, pp.767-776.

http://links.jstor.org/sici?sici=0003-1224\%2819741
2\%2939\%3A6\%3C767\%3AAACA\%3E2.0.CO\%3 B2-Z

[6] Merleau-Ponty, Space, Place, Architecture [M] Ohio University Press, 2015.

[7] Brown, L, Feminist Practices: Interdisciplinary Approaches to Women in Architecture [M] Routledge, 2016. 